\title{
Büyükşehir Belediyeleri ile Bağlı İdarelerde İç Denetimin Etkinliği: Mersin Örneği
}

\author{
The Effectiveness Of Internal Audit In Metropolitan Municipalities And Affiliated \\ Entities: The Mersin Case
}

Ali DERAN*

Orhan Veli ALICI**

\begin{abstract}
$\ddot{O} Z$
Toplumsal düzeyde gereksinim duyulan kamusal nitelikli hizmetlerin giderek çeşitlenmesi neticesinde bu alanlarda faaliyet gösteren idarelerin yönetim süreçleri karmaşık bir hale gelmiştir. Buna bağlı olarak da hizmetlerin ifasında denetimin önemi ve işlerliği elzem bir hal almıştır. Türkiye'de de kentleşme ve nüfus artışı gibi nedenlerle yerel hizmetlerin sunumunda etkin bir denetimin gerekli olduğu anlayışı kabul görmektedir. Bu çalışmada da ülke nüfusunun önemli bir kısmı için mahalli müşterek nitelikli hizmetleri sunan büyükşshir belediyeleri ile bağlı idarelerin denetim süreçleri özetlenerek, özellikle kamu yönetimi paradigmalarında yaşanan değişimle beraber tatbik imkânı bulan iç denetimin etkinliği açıklanacaktır. Genel yönetim kapsamındaki idarelerle beraber anılan idarelerde iç denetim faaliyetinin çıktıları, Sayıştay Başkanlığınca yapılan denetim sonuçlarıyla da mukayese edilecek, akabinde de büyükşehir belediyeleri ve bă̆lı idareleri özelinde mikro bir değerlendirmeye gidebilmek adına Mersin örneği ele alınacaktır.
\end{abstract}

\section{ANAHTAR KELIMELER}

Büyükşsehir Belediyeleri, Bağhl İdareler, İç Denetim, Sayıştay Denetimi, İç Denetçi

\begin{abstract}
Due to the increasing diversity of the qualified public services needed from the social base, the management process of administrations that work on these fields became complicated. Therefore, the importance and functionality of the audits on these services become requisite. In the case of Turkey, because of urbanization and population growth, the necessity of effective audit of local services is accepted. In this article, the audit process of the metropolitan municipalities and affiliated entities that provide local common qualified services to the majority of the population will be summarized, and specifically, the effectiveness of audit that being able to practicable with the paradigm shift of public administration will be examined. The outputs of the internal audits actions of administrations that parallel with general management's affiliated entities will be compared with audit reports of the Turkish Court of Accounts. Thereafter, Mersin will be discussed as an example to make micro-level research on metropolitan municipalities and affiliated entities.
\end{abstract}

\section{KEYWORDS}

Metropolitan Municipalities, Affiliated Entities, Internal Audit, Court of Accounts, Internal Auditor

\begin{tabular}{|c|c|c|}
\hline \multicolumn{2}{|r|}{$\begin{array}{c}\text { Makale Geliş Tarihi / Submission Date } \\
12.11 .2020\end{array}$} & $\begin{array}{c}\text { Makale Kabul Tarihi / Date of Acceptance } \\
23.11 .2020\end{array}$ \\
\hline Atıf & $\begin{array}{l}\text { Deran, A ve Alıc1, O. V. (2020). Büyü } \\
\text { Selcuk Üniversitesi Sosval Bilimler Me }\end{array}$ & $\begin{array}{l}\text { ağl1 İdarelerde İç Denetimin Etkinliği: Mersin Örneği. } \\
\text { si, } 23 \text { (2), 720-735. }\end{array}$ \\
\hline
\end{tabular}

\footnotetext{
* Prof. Dr., Tarsus Üniversitesi, alideran@tarsus.edu.tr, ORCID: 0000-0001-5377-6740

** Doç. Dr., Tarsus Üniversitesi, orhanvelialici@ tarsus.edu.tr, ORCID: 0000-0002-8670-3879
} 


\section{GİRIŞ}

İnsanların bir arada yaşamasıyla beraber ortaya çıkan mahalli müşterek nitelikli hizmetler, zaman içerisinde giderek daha kurumsal yapılar tarafından sunulmaya başlamıştır. Özellikle kent nüfusunun artması ve kentsel alanların mekânsal artışı anılan yerel hizmetlerin çeşitlenmesi sonucunu da doğurmuş, böylece kentsel alanlar için özel ve özerk yönetim mercileri teşekkül ettirilmiştir. Türkiye özelinde de klasik belediye örgütleri kentleşmenin ve nüfus artışının da yaşanmasıyla beraber yerel gereksinimleri karşılamakta güçlük çekmiş, buna bağlı olarak da ilçe belediyelerinin üzerinde kent genelinde eşgüdümü ve yeknesaklığı tesis etmek adına büyükşsehir belediyeleri kurulmuştur. Yine bu zaman zarfında bazı yerel hizmetlerin ihtisas gerektirmesi nedeniyle özel amaçlı metropoliten yerinden yönetim kuruluşlarının kurulması gerekmiştir. Böylece büyükşehir belediyelerine bağlı olmakla birlikte ayrı bir tüzel kişiliği haiz olacak şekilde su ve kanalizasyon idareleri kurularak yaygınlaştırılması yoluna gidilmiştir.

Günümüzde ülke nüfusunun büyük bir kısmının kent nüfusu olması ve yerel gereksinimlerin çeşitlenmesi neticesinde kentsel alan yönetimleri giderek daha karmaşık ve hizmet yoğun bir hale bürünmüsstür. Buna bağlı olarak da hizmetlerin sunum süreçlerinde denetimin önemi de artmıştır. Özellikle yeni kamu yönetimi paradigmalarında vatandaşın bir müşteri olarak görülmesi ve onun memnuniyetinin belirleyici olması da nazara alındığında yerel yönetimlerin gerek iç gerekse de dış denetiminin etkinliğinin de değerlendirilmesi gerekmiştir.

Bu çalışmada öncelikle 5018 sayılı Kamu Mali Yönetimi ve Kontrol Kanunu ile geleneksel teftiş sistemine ek olarak idareler içerisinde teşekkül ettirilen iç denetim faaliyetine değinilecek olup, ülke genelinde iç denetim birimleri arasında eşgüdümü tesis etmek adına teşekkül ettirilen İç Denetim Koordinasyon Kurulu "Kamu İç Denetim Faaliyet Raporları" üzerinden iç denetimin etkinliği tespit edilecektir. Bu çerçevede iç denetçi başına düşen rapor adedi ve çeşitleri göz önünde bulundurularak bir değerlendirmeye gidilecektir. Akabinde de Anayasamızın 160'ıncı maddesi uyarınca TBMM adına hesap denetimi yapan Sayıştay Başkanlığının büyükşehir belediyeleri ile bağlı idareleri özelinde gerçekleştirdiği uygunluk denetimlerinde idareler özelinde tespit ettikleri bulgu sayıları incelenecektir. Daha sonra da iç denetim ile Sayıştay denetiminin mukayesesine gidilecektir.

Çalışmanın son kısmında ise büyükşehir belediyeleri ile bağlı idarelerin iç denetim faaliyetlerinin etkinliği sırasında kentlerin ortalaması esas alındığında denetim raporu sayısı dikkat çeken ve iç denetim faaliyetinin amaca uygun bir şekilde etkin işlediği görülen Mersin Büyükşehir Belediyesi ile Mersin Su ve Kanalizasyon İdaresi Genel Müdürlügünde yürütülen iç denetim faaliyetleri neticesinde tespit edilen bulgu sayılarına ve mahiyetine bakılacaktır. Çalışma bu çerçevede iç denetimin etkinliğini ölçmekle birlikte dış denetime göre daha kazuistik bir muhteviyata büründüğü görüşünü de sınamayı amaç edinmektedir.

\section{1. İÇ DENETIM FAALIYYTİ}

İç denetimin tanımı; iç denetimin temel amacını, niteliğini ve kapsamını belirtmektedir. Uluslararası İç Denetçiler Enstitüsüne (The Institute of Internal Auditors-IIA) göre iç denetim; "bir kurumun faaliyetlerini geliştirmek ve onlara değer katmak amacını güden bağımsız ve objektif bir güvence ve danışmanlık faaliyetidir". Bu anlamda iç denetim "kurumun risk yönetim, kontrol ve yönetişim süreçlerinin etkinliğini değerlendirmek ve geliştirmek amacına yönelik sistemli ve disiplinli bir yaklaşım getirerek kurumun amaçlarına ulaşmasına yardımcı olur" (IIA, 2020). Bu açıklamaya göre bir organizasyonda iç denetimin rolü; bir kuruluşun risk yönetimi, yönetişim ve iç kontrol süreçlerinin etkin bir şekilde işlediğine dair bağımsız güvence sağlayarak danışmanlık faaliyetinde bulunmaktır (The Chartered Institute of Internal Auditors, 2020).

5018 say1lı Kamu Mali Yönetimi ve Kontrol Kanununun 63'üncü maddesine göre ise iç denetim, "kamu idaresinin çalışmalarına değer katmak ve geliştirmek için kaynakların ekonomiklik, etkililik ve verimlilik esaslarına göre yönetilip yönetilmediğini değerlendirmek ve rehberlik yapmak amacıyla yapılan bağımsız, nesnel güvence sağlama ve danışmanlık faaliyetleri” ş̧eklinde tanımlanmıştır. Görüleceği üzere iç denetim faaliyetinin kamu yönetimi paradigmalarındaki değişimle beraber geleneksel teftiş yönteminden önemli düzeyde ayrıldığı, vuku bulan yönetsel ve mali vakalardan önce önleyici bir amaç güttüğü, dolayısıyla da kamu kaynaklarının etkili, ekonomik ve verimli bir şekilde elde edilmesi ve kullanılmasının yanı sıra mali yönetimde hesap verebilirliği ve malî saydamlığı tesis etme amacını da güttüğü anlaşılmaktadır. Anılan maddede ayrıca iç denetim faaliyetinin "idarelerin yönetim ve kontrol yapısı ile malî işlemlerinin, risk yönetimi, yönetim ve kontrol süreçlerinin etkinliğini değerlendirmek ve geliş̧tirmek yönünde sistematik, sürekli ve disiplinli bir yaklaşımla, genel kabul görmüş̧ uluslararası standartlara uygun olarak gerçekleştirileceği”" hususuna da yer verilmiştir. 
İç denetim faaliyetinin idareler özelinde eşgüdüm dâhilinde ve yeknesak bir şekilde yürütülmesi maksadıyla da İç Denetim Koordinasyon Kurulu teşekkül ettirilmiş, bu ve benzeri düzenlemeler suretiyle iç denetimin bağımsızlığı ve tarafsılılığını güvence altına alıcı çeşitli tedbirlerin alındığı da görülmüştür.

İç denetim faaliyetlerinin kapsamı ve alanı konusu da İç Denetçilerin Çalışma Usul ve Esasları Hakkında Yönetmeliğin 6'nc1 ve 7'nci maddelerinde düzenlenmiş̧ir. Bu maddelere göre; iç denetim faaliyeti, kamu idarelerinin bütün birimlerinin işlem ve faaliyetlerini kapsamakta olup, denetim standartlarına uygun olarak risk esaslı denetim plan ve programları çerçevesinde sistematik, sürekli ve disiplinli bir yaklaşım olduğu vurgulanmaktadır. Bu çerçevede iç denetim faaliyetlerinin kapsamını aşağıdaki gibi özetlemek mümkündür (ISMMMO, 2015; 15):

a) Finansal ve operasyonel bilgilerin tanımlanmasında, ölçülmesinde, sinıflandırılmasında, raporlanmasinda kullanilan yöntemlerin doğruluğunun ve güvenilirliğinin incelenmesi.

b) Şirketin/kurumun faaliyetleri ve raporları üzerinde önemli etkiye sahip olan politikalar, planlar, işlemler, yasalar ve düzenlemelere uygunluğu sağlamak amactyla oluşturulan sistemlerin incelenmesi ve şirketin/kurumun faaliyetlerinin bunlara uygun bir şekilde yürütülüp yürütülmediğinin araştırllması.

c) Varlıkların korunma yöntemlerinin gözden geçirilmesi.

c) Harcama kaynaklarının ekonomik ve verimli olarak kullanılıp kullanılmadiğının incelenmesi ve de gerlendirilmesi.

d) Sonuçların şirketin/kurumun amaç ve hedefleriyle tutarlı ve uyumlu olup olmadığını ve faaliyetlerin ve programların planlandığı gibi yürütülüp yürütülmediğinin araştırılması.

e) Denetim Komitesi veya Yönetimin/Yöneticinin talebi üzerine belirli bir işlemin (faaliyetin, olayın) uygun bir şekilde incelenmesi.

İç denetim faaliyetlerinin temel amaçlarını ise aşağıdaki gibi özetlemek mümkündür (Uyar, 2009: 21);

a) Şirketin/kurumun finansal ve finansal olmayan tüm süreçlerinin kontrolüyle birlikte, örgüt tarafindan yürütülen tüm faaliyetlerin etkin, verimli ve yeterli sonuçlar vermesini sağlayarak şirketin/kurumun belirlenen amaç ve hedeflere ulaşmasına katkıda bulunmak.

b) Şirketin/kurumun önceden belirlenmiş örgüt politikalarına uygun faaliyet göstermesini kontrol altında tutmak ve amaçlar, programlar, stratejik planlar, performans planlarl gibi tüm planlara ve yürürlükte olan mevzuata uygun olarak sürdürülebilir örgütsel kalkınmayl sağlamak.

c) Şirketin/kurumun varlıklarının etkin ve verimli olarak kullanılmasını sağlamak, örgüt varlıklarını güvence altina almak.

ç) Muhasebe sistemlerine ilişsin süreçlerin ve iç kontrol sistemlerinin etkinliğini ve verimliliğini incelemek, değerlendirmek ve belirlenen risklerin minimize edilmesine katkl sağlamak.

Yukarıda yer verilen açıklamalardan hareketle iç denetimin amacı; şirketin/kurumun faaliyetlerine ilişkin güvence vermek, ilgili kişi veya kurumlara objektif şekilde bilgi sağlamak, şirketin/kurumun faaliyetlerinin iyileştirilmesi ve sürekli geliştirilmesi yönünde önerilerde bulunmaktır. Söz konusu amaçlar doğrultusunda iç denetim sürecinde; uygunluk denetimi, sistem denetimi, performans denetimi, mali denetim ve bilgi teknolojisi denetimi yapılmaktadır (IDKK, 2020a). Anılan denetimler sırasında faaliyette bulunacak olan iç denetçilerin görevleri ise 5018 sayılı Kanunun 64'üncü maddesi ile İç Denetçilerin Çalışma Usul ve Esasları Hakkında Yönetmeliğin 15'inci maddesinde düzenlenmiştir. Bahsedilen mevzuatta iç denetçilerin görevleri aşağıdaki gibi sayılmıştır;

a) Nesnel risk analizlerine dayanarak kamu idarelerinin yönetim ve kontrol yapılarını değerlendirmek.

b) Kaynakların etkili, ekonomik ve verimli kullanılması bakımından incelemeler yapmak ve önerilerde bulunmak.

c) Harcama sonrasinda yasal uygunluk denetimi yapmak.

c) İdarenin harcamalarının, malî işlemlere ilişkin karar ve tasarruflarının, amaç ve politikalara, kalkınma planına, programlara, stratejik planlara ve performans programlarına uygunluğunu denetlemek ve değerlendirmek.

d) Malî yönetim ve kontrol süreçlerinin sistem denetimini yapmak ve bu konularda önerilerde bulunmak.

e) Denetim sonuçları çerçevesinde iyileştirmelere yönelik önerilerde bulunmak.

f) Denetim sırasında veya denetim sonuçlarına göre soruşturma açılmasinı gerektirecek bir duruma rastlandı̆̆ında, ilgili idarenin en üst amirine bildirmek.

Gerek özel kuruluşlarda gerekse de kamu kurum ve kuruluşlarında iç denetim faaliyetinin aşağıdaki yararlarından bahsetmek mümkündür (Uzun, 2020: 1):

a) Risk ve kontrol değerleme faaliyetlerine destek să̆lar.

b) Şirket/kurum faaliyetlerini izleyerek, faaliyetlere ilişkin risk ve kontrol faaliyetleri ile ilgili önerilerde bulunur, kontrollerin uygunluğunu ve etkinliğini test eder. 
c) Mali denetim, uygunluk denetimi, faaliyet denetimi ve bilgi sistemleri denetimi gibi çeşitli denetim faaliyetlerini içeren iç denetim faaliyeti; şirketlerde/kurumlarda mali raporlama sisteminin güvenilirliği, yasa ve düzenlemelere uygunluk, faaliyetlerin ekonomikliği, etkinliği ve verimliliği, bilgi sistemlerinin güvenliği ve güvenilirliği için makul düzeyde üst yönetime güvence verir.

ç) İ̧ denetim, şirketlerde/kurumlarda yönetsel hesap verebilirliğin yerleşmesine katkı sağlar.

d) Risk yönetiminin bir parçası olarak önleyici bir nitelik taşır.

e) Kurumsal yönetim kalitesini geliştirip, kurumsal değeri yükselterek, pay ve menfaat sahipleri için güvence sağlar.

f) Kurumsal itibarın sigortasidır.

Sertifikalı iç denetçiler eliyle yürütülen iç denetim faaliyeti kapsamında aşağıdaki bölümlerde iç denetim raporlarına yer verilecektir.

\section{2.İÇ DENETIM RAPORLARI}

Doğruluk, tarafsızlık, açıklık, ölçülebilirlik, kısalık, yapıcılık, tamlık, zamanlılık ve kararlılık gibi amaç ve ilkelere sahip olması gereken iç denetim raporları çok çeşitli şekilde hazırlanabilir. En genel tasniflemeyle iç denetim rapor çeşitlerini aşağıdaki gibi özetlemek mümkündür(İSMMMO, 2015; 46).

a) Resmi Raporlar; dikkatlice formatlanarak yapılandırllır.

b) Resmi Olmayan Raporlar; yönetime verilen yazılı not ve memorandumları kapsar.

c) Gelişim Raporları (Ara Raporlar); acil dikkat isteyen konulardaki özet durumları içerir.

c) Sözel Raporlar; resmi görsel-işitsel sunumlar ile resmi olmayan yorumlart içerir.

d) Eksiklik Raporlart; sadece ilgili konulardaki düzeltici faaliyet ihtiyaçlarını yorumlar.

e) Finansal Raporlar; finansal pozisyonları, operasyon sonuçlarını vb. durumları kapsar.

f) Operasyonel Raporlar; kaynakların ekonomik ve verimli kullanımıyla belirlenen hedefler ve amaçlara ulaşma üzerindeki kontrollerin yeterliliği ve etkinliğini değerlendirir.

İç denetim mevzuatı ve rehberine göre ise iç denetim faaliyeti neticesinde denetim, danışmanlık ve inceleme raporları tanzim edilmektedir. Aşağıda bu raporların tanımına yer verilmiştir.

\subsection{Denetim Raporu}

İDKK tarafindan düzenlenen İç Denetim Rehberi’nde "Denetim Raporu” (Audit Report), "denetim görevleri sonucunda hazırlanan ve üst yöneticiye İç Denetim Birimi Başkanı tarafindan sunulan rapor" şeklinde tanımlanmıştır (IDKK, 2013: 171). İç denetim faaliyetine bakıldığında, esas olarak iç denetçiler tarafından en riskli olduğu değerlendirilen süreçlerde denetim faaliyetinde bulunulması gerektiği anlaşılmakta olup, genel olarak idarelerde tanzim edilen denetim raporu adedinin danışmanlık ve inceleme raporu adetlerinden daha fazla olması gerektiği kabul edilmektedir. Söz konusu denetim faaliyeti ise daha önce de değinildiği gibi uygunluk, performans, bilgi teknolojisi, sistem denetimi ve mali denetim şeklinde yapılmaktadır. İç Denetçilerin Çalışma Usul ve Esasları Hakkında Yönetmeliğin 8'inci maddesinde ise anılan denetim türlerinin tanımlarına yer verilmiştir. Buna göre;

-Kamu idarelerinin faaliyet ve işlemlerinin ilgili kanun, tüzük, yönetmelik ve diğer mevzuata uygunluğunun incelenmesi uygunluk denetimi,

-Yönetimin bütün kademelerinde gerçekleştirilen faaliyet ve işlemlerin planlanması, uygulanması ve kontrolü aşamalarındaki etkililiğin, ekonomikliğin ve verimliliğin değerlendirilmesi performans denetimi,

-Gelir, gider, varlık ve yükümlülüklere ilişkin hesap ve işlemlerin doğruluğunun; mali sistem ve tabloların güvenilirliğinin değerlendirilmesi mali denetim,

-Denetlenen birimin elektronik bilgi sistemlerinin sürekliliğinin ve güvenilirliğinin değerlendirilmesi bilgi teknolojisi denetimi,

-Denetlenen birimin faaliyetlerinin ve iç kontrol sisteminin; organizasyon yapısına katkı sağlayıcı bir yaklaşımla analiz edilmesi, eksikliklerinin tespit edilmesi, kalite ve uygunluğunun araştırılması, kaynakların ve uygulanan yöntemlerin yeterliliğinin ölçülmesi suretiyle değerlendirilmesi de sistem denetimi olarak tanımlanmıştır.

\subsection{Danışmanlık Raporu}

İç Denetim Rehberi’ne göre Danışmanlık Raporu; “İdarenin hedeflerini gerçekleştirmeye yönelik kurumsal yönetim, risk yönetimi ve iç kontrol faaliyetlerinin ve süreçlerinin sistematik bir biçimde değerlendirilmesi ve geliştirilmesine yönelik önerilerde bulunulması neticesinde tanzim edilen rapor” ş̧eklinde tanımlanmıştır (IDKK, 2013: 170). İç denetçilerce yapılan risk değerlendirmesi ile birlikte ilgili birimlerden gelen talepler de dikkate alınarak denetim programı kapsamında yıllık danışmanlık faaliyetlerine de yer verilmektedir. 
Denetimden ziyade, riski asgariye indirgeyici tedbirleri ön plana alan ve önleyici bir mahiyet içeren danışmanlık faaliyeti birim faaliyetlerinde veya belirli bir konuda iyileştirici bir fonksiyon üstlenmektedir.

\subsection{Inceleme Raporu}

İç Denetim Rehberi’ne göre İnceleme Raporu (Examination Report), “usulsüzlük ve yolsuzluk iddia ve tespitlerine ilişkin olarak yapılan incelemeler sonucunda iç denetçiler tarafindan düzenlenen rapor" şeklinde tanımlanmıştır (IDKK, 2013: 174). Denetim veya danışmanlık faaliyeti sırasında veya üst yönetici tarafından ya da başka bir yolla iç denetim birimine iletilen usulsüzlük ve yolsuzluk iddialarının ortaya çıkması ve şüphenin kuvvetli bir hal alması neticesinde iç denetçiler tarafından tanzim edilen bu rapor sayısının asgari olması beklenmektedir. Nitekim Türkiye özelinde iç denetçi kadrosu ihdas edilen idareler esas alındığında üniversiteler dıșında kalan idarelerde teftiş mekanizması da bulunmaktadır. Dolayısıyla her ne kadar iç denetimin yetkisi olsa da usulsüzlük ve yolsuzluk iddialarında genellikle teftiş kurullarının çalıştıııldıkları görülmektedir. Bu bakımdan inceleme raporu adedinin ise olabildiğince az sayıda olması beklenmektedir.

\section{3. İÇ DENETÇİ KADROSU İHDAS EDİLEN İDARELERDE DENETIM FAALIYYETLERİ}

5018 sayılı Kanunun tatbikiyle beraber Türkiye'de geleneksel teftiş yönteminin yanı sıra iç kontrolün bir bileşeni olarak iç denetim faaliyetinin de uygulanması süreci başlatılmıştır. 2018 yılı Kamu İç Denetim Faaliyet Raporu'na göre genel yönetim kapsamındaki idarelerin 253 adetinde iç denetçi atamaları yapılmış ve iç denetim faaliyeti sürecine başlanılmıştır. Ancak 123 idarede henüz iç denetçi ataması yapılmamıştır. Bu verilere göre genel yönetim kapsamındaki idarelerin \%32'sinde iç denetim faaliyetinin başlatılmadığ anlaşılmaktadır (IDKK, 2020b: 34). Hâlihazırda ihdas edilen 2067 adet iç denetçi kadrosunun ise 867 adetinin 2020 yılı itibariyle dolu olduğu, 1200 adetinin ise boş olduğu (IDKK, 2020c); 2018 y1lında ise 2054 adet iç denetçi kadrosunun 880 adetinin dolu olduğu, 1174 adetinin ise boş olduğu tespit edilmiştir (IDKK, 2018).

Aşağıdaki tabloda 2015-2018 yılları arasında iç denetçi kadrosuna atama yapan idareler kapsamında yapılan denetim, danışmanlık ve inceleme raporları hakkında sayısal anlamda bilgi verilmiştir.

Tablo 1: İç Denetçi Kadrosu İhdas Edilen İdarelerdeki Rapor Sayıları

\begin{tabular}{|l|c|c|c|}
\hline İdareler & Denetim Raporu & Danışmanlık Raporu & Inceleme Raporu \\
\hline $\mathbf{2 0 1 5}$ & 952 & 399 & 143 \\
\hline $\mathbf{2 0 1 6}$ & 1.022 & 300 & 192 \\
\hline $\mathbf{2 0 1 7}$ & 994 & 355 & 168 \\
\hline $\mathbf{2 0 1 8}$ & 884 & 345 & 233 \\
\hline Ortalama & 963 & 349,75 & 184 \\
\hline $\begin{array}{l}\text { İç Denetçi Başına Düşen } \\
\text { Ortalama Rapor Sayıs1 }\end{array}$ & 1,09 & 0,397 & 0,2 \\
\hline
\end{tabular}

Kaynak: İç Denetim Koordinasyon Kurulu 2015-2018 yılları Faaliyet Raporlarından derlenmiştir. https://www.hmb.gov.tr/idkk-faaliyet-raporlari

Tablo 1'e göre 2015-2018 yılları arasında yıllık ortalama denetim raporu sayısının 963 olduğu, denetçi başına da 1,09 denetim raporu sayısının düştüğü; danışmanlık raporunda ise yıllık ortalama rapor sayısının 349,75 adet olduğu, iç denetçi başına düşen danışmanlık raporu sayısının da yaklaşık 0,4 olduğu; sadece usulsüzlük ve yolsuzluk durumlarında tanzim edilen inceleme raporunun yıllık ortalamasının da 184 olduğu, iç denetçi başına düşen ortalama rapor sayısının da 0,2 olarak gerçekleştiği anlaşılmaktadır.

Söz konusu verilerin denetim, danışmanlık ve inceleme raporlarını kapsayacak şekilde toplam rapor sayıları üzerinden de değerlendirilmesinde fayda bulunmaktadır.

\section{Tablo 2: İç Denetçi Kadrosu İhdas Edilen İdarelerdeki Toplam Rapor Sayıları}

\begin{tabular}{|l|l|l|l|l|}
\hline Idareler & $\mathbf{2 0 1 5}$ & $\mathbf{2 0 1 6}$ & $\mathbf{2 0 1 7}$ & $\mathbf{2 0 1 8}$ \\
\hline Toplam Rapor Sayısı & 1.494 & 1.514 & 1.517 & 1.496 \\
\hline Ortalama Rapor Sayısı & \multicolumn{4}{|c|}{$1.505,25$} \\
\hline İç Denetçi Başına Düşen Rapor Sayısı & \multicolumn{4}{|c|}{1,73} \\
\hline
\end{tabular}

Kaynak: İç Denetim Koordinasyon Kurulu 2015-2018 yılları Faaliyet Raporlarından derlenmiştir. https://www.hmb.gov.tr/idkk-faaliyet-raporlari

2018 yılı itibarıyla tanzim edilen toplam denetim, danışmanlık ve inceleme rapor sayısının 1496 adet, 2017 y1lında 1.517 adet, 2016 yılında 1.514 adet, 2015 y1lında da 1.494 adet olduğu; neticede de toplam ortalama rapor sayısının 1.505,25 adet, iç denetçi başına düşen ortalama rapor sayısının da 1,73 adet olduğu tespit edilmiştir. Edinilen bu makro veriler nazara alınarak aşağıda büyükşehir belediyeleri ve bağlı idarelerin iç denetim faaliyeti kapsamındaki toplam rapor sayısı ile iç denetçi başına düşen rapor sayısına yer verilecektir. 


\section{4. İÇ DENETÇİ KADROSU İHDAS EDİLEN BÜYÜKŞEHİR BELEDIYYLLERİ İLE BAĞLI IDARELERDE İÇ DENETIM FAALIYETLERI}

Çalışma kapsamında İDKK tarafından hazırlanan faaliyet raporlarında yer alan bilgilerin mahalli idareler özelinde ele alınması gerekmiş olup, söz konusu veriler üzerinden iç denetim sisteminin etkinliğinin değerlendirilmesi amaçlanmıştır. Ancak anılan idarelerin sayısal fazlalığı da nazara alınarak sadece büyükşehir belediyeleri ile bağlı idarelerin incelenmesi gerekliliği hâsıl olmuştur.

Aşağıdaki tabloda IDKK tarafından düzenlenen faaliyet raporlarında yer alan bilgiler büyükşehir belediyeleri ile bağl1 idareler özelinde tasnif edilerek tablo haline getirilmiştir. Bu veriler ile genel olarak 5018 sayılı Kanun kapsamında olan ve iç denetçi kadrosu ihdas edilen genel yönetim kapsamındaki idarelerin iç denetim faaliyetleri ile büyükşehir belediyeleri ile bağlı idarelerinde gerçekleşen iç denetim faaliyetinin mukayese edilmesi amaçlanmıştır.

12/7/2006 tarih ve 26226 sayılı Resmî Gazete'de yayımlanan İç Denetçilerin Çalışma Usul ve Esasları Hakkında Yönetmeliğin 45'inci maddesinde "İç denetim raporları ile bunlar üzerine yapılan işlemler, raporun üst yöneticiye sunulduğu tarihten itibaren iki ay içinde Kurula gönderilir" hükmü yer almakta olup, bu kaide gereğince üst yöneticiye sunulan ve nihayete eren raporların IDKK'ye de gönderilmesi gerekmektedir. Çalışma kapsamındaki edinilen verilerin tamamı üst yönetici tarafından İDKK'ye gönderilen raporlara istinaden edinilen verilerden oluşmaktadır.

Tablo 3: Büyükşehir Belediyelerinde İç Denetim Raporları (Dn:Denetim R.; Da: Danışmanlık R.; İnc.:İnceleme R.)

\begin{tabular}{|c|c|c|c|c|c|c|c|c|c|c|c|c|}
\hline \multirow{2}{*}{ Büyükşehir Belediyesi } & \multicolumn{3}{|c|}{2015} & \multicolumn{3}{|c|}{2016} & \multicolumn{3}{|c|}{2017} & \multicolumn{3}{|c|}{2018} \\
\hline & Dn. & Da. & İnc. & Dn. & Da. & İnc. & Dn. & Da. & İnc. & Dn. & Da. & İnc. \\
\hline Adana & 8 & - & - & 12 & - & - & 6 & 0 & 0 & 6 & 0 & 0 \\
\hline Ankara & 19 & - & - & 16 & - & - & 16 & 5 & 0 & 22 & 5 & 0 \\
\hline Antalya & 8 & 10 & 7 & 6 & 9 & 14 & 9 & 17 & 1 & 8 & 24 & 0 \\
\hline Aydın & 6 & - & - & 14 & - & - & - & - & - & 6 & 0 & 0 \\
\hline Balıkesir & - & - & - & - & - & - & - & - & - & - & - & - \\
\hline Bursa & 9 & 4 & - & 5 & - & 1 & 2 & 0 & 0 & 2 & 0 & 0 \\
\hline Denizli & - & - & - & 10 & - & - & - & - & - & 5 & 0 & 0 \\
\hline Diyarbakır & 6 & 1 & 1 & 1 & - & 1 & 7 & 0 & 2 & 8 & 0 & 0 \\
\hline Erzurum & - & - & - & - & - & - & - & - & - & - & - & - \\
\hline Eskişehir & - & - & - & - & - & - & - & - & - & - & - & - \\
\hline Gaziantep & 10 & 1 & - & 5 & 4 & - & 4 & - & - & 0 & 7 & 0 \\
\hline Hatay & - & - & - & 14 & - & - & - & - & - & 2 & 0 & 1 \\
\hline İstanbul & - & - & - & - & - & - & - & - & - & - & - & - \\
\hline İzmir & 15 & 5 & - & 17 & 5 & - & 21 & 4 & 0 & 23 & 0 & 0 \\
\hline Kahramanmaraş & 3 & 1 & - & - & - & 2 & - & - & - & - & - & - \\
\hline Kayseri & - & - & - & - & - & - & - & - & - & - & - & - \\
\hline Kocaeli & - & - & - & - & - & - & - & - & - & - & - & - \\
\hline Konya & - & - & - & - & - & - & - & - & - & - & - & - \\
\hline Malatya & - & - & - & - & - & - & - & - & - & - & - & - \\
\hline Manisa & - & - & - & 7 & - & - & 6 & 0 & 0 & 5 & 0 & 0 \\
\hline Mardin & - & - & - & - & - & - & - & - & - & - & - & - \\
\hline Mersin & 10 & - & 2 & 11 & - & - & 19 & 0 & 0 & 6 & 39 & 0 \\
\hline Muğla & - & 2 & - & - & 1 & - & 0 & 3 & 3 & - & - & - \\
\hline Ordu & - & - & - & - & - & - & - & - & - & - & - & - \\
\hline Sakarya & 2 & 2 & - & - & - & - & - & - & - & - & - & - \\
\hline Samsun & - & - & - & - & - & - & - & - & - & - & - & - \\
\hline Şanlıurfa & - & - & - & - & - & - & - & - & - & - & - & - \\
\hline Tekirdağ & - & - & - & - & - & - & - & - & - & - & - & - \\
\hline Trabzon & - & - & - & - & - & - & - & - & - & - & - & - \\
\hline Van & - & - & - & - & - & - & - & - & - & - & - & - \\
\hline
\end{tabular}

Kaynak: IDDKK 2015-2018 yılı Faaliyet Raporları verilerinden yararlanılarak hazırlanmıştır.

Yukarıdaki tabloda büyükşehir belediyeleri tarafından nihayete erdirilen iç denetim faaliyetleri neticesinde hazırlanan rapor adetlerine yer verilmiştir. Aşağıda ise söz konusu verilerin 2015-2018 yılları kapsamında ele alınarak iç denetçi sayıları ile mukayese edilmesi gerekmiştir. 
Tablo 4: Büyükşehir Belediyelerinde İç Denetim Faaliyetinin Etkinliği (Dn:Denetim R.; Da: Danışmanlık R.; İnc.:İnceleme R.)

\begin{tabular}{|c|c|c|c|c|c|c|c|}
\hline \multirow{2}{*}{$\begin{array}{l}\text { Büyükşehir } \\
\text { Belediyesi }\end{array}$} & \multicolumn{4}{|c|}{$\begin{array}{l}\text { 2015-2018 Toplam Rapor } \\
\text { Sayısı }\end{array}$} & \multirow{2}{*}{$\begin{array}{l}\text { İç } \\
\text { Denetçi } \\
\text { Sayısı }\end{array}$} & \multirow{2}{*}{$\begin{array}{l}\text { Yıllık Ortalama İç Denetçi } \\
\text { Başına Düssen Rapor Sayısı } \\
\text { (Yıllık Ortalama/ } \\
\text { Denetçi) }\end{array}$} & \multirow{2}{*}{$\begin{array}{l}\text { İç Denetçi Başına } \\
\text { Düşsen Rapor Sayısı } \\
\text { (Toplam Rapor/ } \\
\text { Denetçi) }\end{array}$} \\
\hline & Dn. & Da. & İnc. & Toplam & & & \\
\hline Adana & 32 & 0 & 0 & 32 & 6 & 1,33 & 5,33 \\
\hline Ankara & 73 & 10 & 0 & 83 & 7 & 2,96 & 11,85 \\
\hline Antalya & 31 & 60 & 22 & 113 & 5 & 5,65 & 22,60 \\
\hline Aydın & 26 & 0 & 0 & 26 & 2 & 3,25 & 13,00 \\
\hline Balıkesir & - & - & - & - & 2 & - & - \\
\hline Bursa & 18 & 4 & 1 & 23 & 2 & 2,87 & 11,50 \\
\hline Denizli & 15 & 0 & 0 & 15 & 2 & 1,87 & 7,50 \\
\hline Diyarbakır & 22 & 1 & 4 & 27 & 3 & 2,25 & 9,00 \\
\hline Erzurum & - & - & - & - & 1 & - & - \\
\hline Eskişehir & - & - & - & - & 1 & - & - \\
\hline Gaziantep & 19 & 12 & 0 & 31 & 4 & 1,93 & 7,75 \\
\hline Hatay & 16 & 0 & 1 & 17 & 2 & 2,12 & 8,50 \\
\hline İstanbul & - & - & - & - & 15 & - & - \\
\hline İzmir & 76 & 14 & 0 & 90 & 10 & 2,25 & 9,00 \\
\hline Kahramanmaraş & 3 & 1 & 2 & 6 & 4 & 0,37 & 1,50 \\
\hline Kayseri & - & - & - & - & 1 & - & - \\
\hline Kocaeli & - & - & - & - & 0 & - & - \\
\hline Konya & - & - & - & - & 3 & - & - \\
\hline Malatya & - & - & - & - & 2 & - & - \\
\hline Manisa & 18 & 0 & 0 & 18 & 2 & 2,25 & 9,00 \\
\hline Mardin & - & - & - & - & 0 & - & - \\
\hline Mersin & 46 & 39 & 2 & 87 & 7 & 3,10 & 12,42 \\
\hline Muğla & 0 & 6 & 3 & 9 & 1 & 2,25 & 9,00 \\
\hline Ordu & - & - & - & - & 2 & - & - \\
\hline Sakarya & 2 & 2 & 0 & 4 & 2 & 0,50 & 2,00 \\
\hline Samsun & - & - & - & - & 2 & - & - \\
\hline Şanlıurfa & - & - & - & - & 1 & - & - \\
\hline Tekirdağ & - & - & - & - & 0 & - & - \\
\hline Trabzon & - & - & - & - & 2 & - & - \\
\hline Van & - & - & - & - & 1 & - & - \\
\hline Toplam & 397 & 149 & 35 & 581 & 92 & 1,57 & 6,31 \\
\hline
\end{tabular}

Kaynak: İDKK 2015-2018 yılı Faaliyet Raporları verilerinden yararlanılarak hazırlanmıştır. İç Denetçi sayısı ise 2015-2018 dönemindeki değişim dikkate alınarak tespit edilmiştir.

Yukarıdaki tabloya göre 2015-2018 döneminde 30 büyükşehir belediyesinin 15'inde iç denetim faaliyetinin devam ettiği, diğer 15 büyükşsehir belediyesinin de 3'ünde iç denetçi atamasının yapılmadığı, 12 büyükşehir belediyesinde ise iç denetim faaliyetinin aktif hale getirilmediği veya hazırlanan raporların IDKK'ye gönderilmediği anlaşılmıştır. Nitekim 20 adet iç denetçi kadrosu ihdas edilen ve 15 adet iç denetçi istihdam edilen İstanbul Büyükşehir Belediyesi tarafindan iç denetim faaliyetleri neticesinde hazırlanan raporların da İDKK'ye gönderilmediği anlaşılmaktadır. Diğer taraftan iç denetçi ataması yapılmasına rağmen iç denetim faaliyetini işler hale getirmeyen veya iç denetçi ataması yapmayan idarelere de Sayıştay tarafından yapılan denetimlerde yer verilmektedir. Sayıştay tarafından yapılan denetimlerde Hatay Büyükşehir Belediyesinde "İç Denetim Birimi İhdas Edilmesine Rağmen Rapor Üretilmemesi”, Kayseri Büyükşehir Belediyesinde "İç Denetçi Kadroları Bulunmasına Rağmen $\mathrm{Bu}$ Kadrolara Atama Yapılmaması ve İç Denetim Raporu Düzenlenmemesi”, Şanlıurfa Büyükşehir Belediyesinde de “İç Denetim Raporu Düzenlenmemesi” bulgularına yer verildiği görülmüştür (Sayıştay, 2016).

Tekrar tablodaki verilere dönersek, iç denetim faaliyeti sonucunu IDKK'ye bildirim yükümlülügünü yerine getiren 15 büyükşehir belediyesi özelinde 4 yıllık süre zarfinca toplam 581 adet denetim raporunun üretildiği, bu idarelerde ise toplam 59 adet iç denetçinin istihdam edildiği, dolayısıyla da yıllık bazda iç denetçi başına düşen rapor sayısının 2,46 adet olduğu, 2015-2018 dönemindeki toplam iç denetçi başına düşen rapor sayısının ise 9,84 adet olarak gerçekleştiği anlaşılmaktadır. Tablo 2'deki verilerle mukayese edildiğinde 5018 sayılı Kanun kapsamında faaliyet gösteren bütün idareler özelinde 2015-2018 yılları arasında 6.021 adet üretilen 
raporun 581 adetinin, yani \%9,6'sının 15 büyükşehir belediyesine ait olduğu anlaş1lmaktadır. Diğer taraftan iç denetçi başına düşen yıllık ortalama rapor sayısı 1,73 iken 15 büyükşehir belediyesinde iç denetçi başına düşen rapor sayısının 2,46 olduğu anlaşılmaktadır. Bu veriler nazara alındığında genel yönetim kapsamındaki idarelerin ortalamasına göre 15 adet büyükşehir belediyesinde iç denetim faaliyetinin etkili bir şekilde işlediği görülmektedir.

Söz konusu büyükşehir belediyelerinde ise denetçi başına düşen rapor sayısının en fazla olduğu Antalya Büyükşsehir Belediyesinin raporları da incelendiğinde danışmanlık raporlarının ağırlıkta olduğu, bu idare özelinde de iç denetçilerin uzmanlık alanları nazara alınarak bilhassa belediyenin taşınmazları ile ilgili konularda yaşanan uyuşmazlıklar konusunda danışmanlık raporlarının üretildiği gözlemlenmiştir.

Büyükşehir belediyelerine bağlı idarelere gelince, 6360 sayılı Kanun ile 14 ilde büyükşehir belediyesi kurulmuş, bu yerlerde ayrıca su ve kanalizasyon idareleri de teşekkül ettirilmiştir. Ancak yeni kurulan su ve kanalizasyon idareleri için IDKK tarafından kadro ihdasında bulunulmamıştır. Bu çerçevede 16 adet su ve kanalizasyon idaresi ile üç büyük metropolde bulunan ulaşım otoriteleri çalışmanın kapsamına girmiştir. Aşağıdaki tabloda toplam 19 adet büyükşehir belediyelerine bağlı idarenin 2015-2018 yılları arasındaki rapor adetlerine yer verilmiştir.

\section{Tablo 5: Büyükşehir Belediyelerine Bağlı İdarelerde İç Denetim Raporları}

\begin{tabular}{|l|c|c|c|c|c|c|c|c|c|c|c|c|}
\hline \multirow{2}{*}{ İdare Adı } & \multicolumn{3}{|c|}{$\mathbf{2 0 1 5}$} & \multicolumn{3}{|c|}{$\mathbf{2 0 1 6}$} & \multicolumn{3}{c|}{$\mathbf{2 0 1 7}$} & \multicolumn{3}{|c|}{$\mathbf{2 0 1 8}$} \\
\cline { 2 - 16 } & Dn. & Da. & İnc. & Dn. & Da. & İnc. & Dn. & Da. & İnc. & Dn. & Da. & İnc. \\
\hline Adana ASKİ & 0 & 0 & 0 & 0 & 0 & 0 & 1 & 0 & 0 & 1 & 0 & 0 \\
\hline Ankara ASKİ & 5 & 1 & 0 & 1 & 1 & 0 & 6 & 0 & 1 & 6 & 2 & 0 \\
\hline Antalya ASAT & 0 & 0 & 0 & 0 & 0 & 2 & 0 & 12 & 0 & 0 & 0 & 22 \\
\hline Bursa BUSKİ & 4 & 1 & 0 & 4 & 6 & 0 & 0 & 0 & 0 & 1 & 2 & 0 \\
\hline Diyarbakır DİSKİ & 0 & 0 & 0 & 0 & 0 & 0 & 1 & 0 & 0 & 0 & 0 & 0 \\
\hline Erzurum ESKİ & - & - & - & - & - & - & - & - & - & - & - & - \\
\hline Eskişehir ESKİ & 0 & 0 & 0 & 0 & 0 & 0 & 7 & 3 & 0 & 0 & 1 & 0 \\
\hline Gaziantep GASKI & 0 & 0 & 0 & 0 & 0 & 0 & 0 & 0 & 0 & 0 & 0 & 0 \\
\hline İstanbul İSKİ & 8 & 0 & 0 & 8 & 0 & 0 & 6 & 0 & 0 & 3 & 3 & 11 \\
\hline İzmir İZSU & 4 & 3 & 1 & 5 & 5 & 1 & 6 & 2 & 1 & 4 & 0 & 0 \\
\hline Kayseri KASKİ & - & - & - & - & - & - & - & - & - & - & - & - \\
\hline Kocaeli İSU & 1 & 6 & - & 4 & 10 & - & 8 & 16 & 0 & 6 & 14 & 0 \\
\hline Konya KOSKİ & - & - & - & - & - & - & - & - & - & - & - & - \\
\hline Mersin MESKİ & 4 & 3 & 10 & 4 & 1 & 11 & 1 & 2 & 0 & 1 & 2 & 0 \\
\hline Sakarya SASKI & - & - & - & - & - & - & - & - & - & - & - & - \\
\hline Samsun SASKİ & 1 & 0 & 0 & 1 & 0 & 0 & 2 & 0 & 0 & 0 & 0 & 0 \\
\hline İETT & 5 & 3 & 0 & 2 & 4 & 0 & 2 & 1 & 1 & 4 & 3 & 0 \\
\hline EGO & 0 & 0 & 0 & 0 & 3 & 0 & 0 & 4 & 0 & 0 & 0 & 1 \\
\hline ESHOT & 3 & 1 & 0 & 7 & 0 & 0 & 7 & 3 & 0 & 7 & 0 & 0 \\
\hline
\end{tabular}

Kaynak: IDKK 2015-2018 yılı Faaliyet Raporları verilerinden yararlanılarak hazırlanmıştır.

Yukarıdaki tabloda bağlı idareler tarafından nihayete erdirilen iç denetim faaliyetleri neticesinde hazırlanan rapor adetlerine yer verilmiştir. Aşağıda da söz konusu verilerin 2015-2018 yılları kapsamında ele alınarak iç denetçi sayıları ile mukayese edilmesi gerekmiştir. Tablo 6'da ise söz konusu raporların toplamına ve iç denetçi sayıları ile olan mukayesesine yer verilmiştir.

Tablo 6: Büyükşehir Belediyelerine Bağlı İdarelerde İç Denetim Faaliyetinin Etkinliği

\begin{tabular}{|c|c|c|c|c|c|c|c|}
\hline \multirow{2}{*}{ İdare Adı } & \multicolumn{4}{|c|}{$\begin{array}{lll}\begin{array}{l}\text { 2015-2018 } \\
\text { Sayısı }\end{array} & \text { Toplam } & \text { Rapor } \\
\end{array}$} & \multirow{2}{*}{$\begin{array}{l}\text { İç } \\
\text { Denetçi } \\
\text { Sayısı }\end{array}$} & \multirow{2}{*}{$\begin{array}{l}\text { Yıllık Ortalama İç Denetçi } \\
\text { Başına Düşen Rapor Sayısı } \\
\text { (Yıllık Ortalama/Denetçi) }\end{array}$} & \multirow{2}{*}{$\begin{array}{|lrr|}\text { İç } & \text { Denetçi } & \text { Başına } \\
\text { Düşen Rapor Sayısı } \\
\text { (Toplam } & \text { Rapor/ } \\
\text { Denetçi) } & \\
\end{array}$} \\
\hline & Dn. & Da. & İnc. & Toplam & & & \\
\hline Adana ASKİ & 2 & 0 & 0 & 2 & 1 & 0,50 & 2,00 \\
\hline Ankara ASKİ & 18 & 4 & 1 & 23 & 5 & 1,15 & 4,60 \\
\hline Antalya ASAT & 0 & 12 & 24 & 36 & 1 & 9,00 & 36,00 \\
\hline Bursa BUSKİ & 9 & 9 & 0 & 18 & 1 & 4,50 & 18,00 \\
\hline Diyarbakır DİSKİ & 1 & 0 & 0 & 1 & 1 & 0,25 & 1,00 \\
\hline Erzurum ESKİ & - & - & - & - & 0 & - & - \\
\hline Eskişehir ESKİ & 7 & 4 & 0 & 11 & 1 & 2,75 & 11,00 \\
\hline Gaziantep GASKI & - & - & - & - & 0 & - & - \\
\hline
\end{tabular}




\begin{tabular}{|c|c|c|c|c|c|c|c|}
\hline İstanbul İSKI & 25 & 3 & 11 & 39 & 4 & 2,43 & 9,75 \\
\hline İzmir İZSU & 19 & 10 & 3 & 32 & 5 & 1,60 & 6,40 \\
\hline Kayseri KASKİ & - & - & - & - & 0 & - & - \\
\hline Kocaeli İSU & 19 & 46 & 0 & 65 & 3 & 5,41 & 21,66 \\
\hline Konya KOSKI & - & - & - & - & 1 & - & - \\
\hline Mersin MESKİ & 10 & 8 & 21 & 39 & 1 & 9,75 & 39,00 \\
\hline Sakarya SASKI & - & - & - & - & 0 & - & - \\
\hline Samsun SASKİ & 4 & 0 & 0 & 4 & 1 & 1,00 & 4,00 \\
\hline İETT & 13 & 11 & 1 & 25 & 2 & 3,12 & 12,50 \\
\hline EGO & 0 & 7 & 1 & 8 & 1 & 2,00 & 8,00 \\
\hline ESHOT & 24 & 4 & 0 & 28 & 3 & 2,33 & 9,33 \\
\hline Toplam & 151 & 118 & 62 & 331 & 31 & 2,67 & 10,67 \\
\hline
\end{tabular}

Kaynak: İDKK 2015-2018 yılı Faaliyet Raporları verilerinden yararlanılarak hazırlanmıştır.

Tabloya göre iç denetçisi olmasına rağmen rapor tanzim etmeyen veya etse de İDKK'ye göndermeyen bir bağlı idarenin bulunmadığı anlaşılmaktadır. Bu çerçevede 2015-2018 yılları arasında toplam 31 iç denetçi tarafından 331 adet rapor tanzim edildiği, iç denetçi başına rapor sayısının 10,67 olduğu, yıllık bazda ise bu oranın 2,67 olduğu anlaşılmaktadır. Tablo 2'deki verilerle mukayese edildiğinde 2015-2018 y1lları arasında üretilen 6.021 adet raporun 331 adetinin, yani \%5,5'inin 14 büyükşehir belediyesine bağl1 olan idareye ait olduğu görülmektedir. Diğer taraftan iç denetçi başına düşen yıllık ortalama rapor sayıs1 1,73 iken söz konusu bağlı idarelerde bu sayının 2,67'ye tekabül ettiği anlaşılmaktadır. Bu çerçevede gerek genel yönetim kapsamındaki idare ortalaması gerekse de büyükşehir belediyeleri ortalamasına göre iç denetim faaliyetinin bağl1 idarelerde etkili bir şekilde işlediği görülmektedir.

Ancak iç denetçi kadrosu ihdas edilmesine rağmen Erzurum, Gaziantep, Kayseri ve Sakarya Su ve Kanalizasyon İdarelerinde iç denetçi ataması yapılmadığı, dolayısıyla da iç denetim faaliyetinde bulunulmadığı görülmektedir. Bu kapsamda 2015-2018 yılları arasında söz konusu idarelerde yapılan Sayıştay denetim raporları incelenmiş, sadece 2015 yılında Erzurum Su ve Kanalizasyon İdaresi Genel Müdürlüğünde yapılan denetimde "Erzurum Su ve Kanalizasyon İdaresinde İç Denetim Biriminin Kurulmamış Olması" bulgusuna yer verildiği anlaşılmıştır (Sayıştay, 2016: 13). Bu tespitin aynı denetim erkince sadece Erzurum özelinde tespit edilmesine rağmen diğer önemli büyükşehir belediyelerine bağlı idarelerde tespit edilmemesi veya tespit edilse dahi bir bulgu halinde işlem görmemesi Sayıştay Denetimleri sırasında eşgüdüm ve yeknesaklığın yeterince geçerli olmadığını göstermektedir.

İç denetim faaliyetinin daha etkin hale getirilmesi adına İç Denetim Koordinasyon Kurulu tarafindan da çeşitli aksiyonların alındığı görülmektedir. Süregelen zaman içerisinde İDKK tarafından iç denetçi ataması yapmayan idarelere çeşitli yazılar yazılarak iç denetim faaliyetinin etkin hale getirilmesi noktasında bu idarelerin tekit edildiği anlaşılmıştır. İKK tarafından iç denetçi kadrosu ihdas edilmiş bütün idarelere gönderilen 02/10/2020 tarih ve 549005 sayılı yazıda ise halihazırda ihdas edilen iç denetçi sayılarının yeterli olup olmadığı, yeterli değilse talep edilen iç denetçi sayısı ile iç denetçi ataması yapmayan idarelerden neden iç denetçi ataması yapılmadığının gerekçesi istenilmiştir. Bu hususlar nazara alındığında iç denetçi atamalarının yapılarak iç denetim faaliyetinin aktif hale getirilmesi noktasında İDKK'nin gerekli aksiyonları aldığı görülmektedir (IDKK, 2020d).

\section{BÜYÜKŞEHİR BELEDIYYELERİ İLE BAĞLI İDARELERDE GERÇEKLEŞTİRİLEN SAYIŞTAY DENETIMI}

Dayanağını 1982 Anayasasının 160'ıncı maddesinden alan Sayıştay, TBMM adına genel yönetim kapsamındaki idarelerin gelir, gider ve mallarını denetleyerek sorumluların hesap ve işlemlerini kesin hükme bağlamak ve kanunlarla verilen inceleme, denetleme ve hükme bağlama işlerini yapmakla yetkili kılınmıştır. 6085 sayılı Sayıştay Kanununun 34'üncü maddesine istinaden Sayıştay;

a) Bütçe hakkının gereği olarak kamu idarelerinin faaliyet sonuçları hakkında Türkiye Büyük Millet Meclisine ve kamuoyuna güvenilir ve yeterli bilgi sunulmasl,

b) Kamu mali yönetiminin hukuka uygun olarak yürütülmesi ve kamu kaynaklarının korunması,

c) Kamu idarelerinin performansinın değerlendirilmesi,

ç) Hesap verme sorumluluğu ve mali saydamlığın yerleştirilmesi ve yaygınlaş̧tırılması,

amaciyla denetim gerçekleştirilmektedir.

Söz konusu denetimler ise düzenlilik ve performans denetimi altında gerçekleştirilmekte, düzenlilik denetimi de mali ve uygunluk denetimi şeklinde ikiye ayrılmaktadır. Sayıştay Başkanlığı tarafından yapılan denetimlerde, denetim görüşünü destekleyecek mahiyette bulgulara yer verilmektedir. Ancak denetim görüşünü etkilemeyen bulgular da bu raporda yer almaktadır. Mali rapor ve tabloları etkilemeyen, başka bir 
deyişle denetim görüşünü etkilemeyen bulgular ile hukuki düzenlemelere uygunluk açısından eleştiri konusu yapılan hususlar "denetim görüşünü etkilemeyecek bulgular" şeklinde tasnif edilmektedir. Bu nedenle denetim görüşünü etkileyen bulgular önem arz etmekte olup büyükşehir belediyeleri ile bağlı idarelerin Sayıştay tarafından denetimi neticesinde hazırlanan raporlarda yer alan ve denetim görüşünü etkileyen bulgulara yer verilmiştir.

Aşağıdaki tabloda 2015 ile 2018 yılları arasındaki dört yıllık süre zarfında büyükşehir belediyeleri ve bağlı idarelerinde yapılan Sayıştay denetimi neticesinde tespit edilen ve denetim görüşü oluşturmaya imkân tanıyan bulgu adetlerine yer verilmiştir.

Tablo 7: Büyükşehir Belediyelerinde Sayıştay Denetimi Bulgu Sayıları

\begin{tabular}{|l|c|c|c|c|c|}
\hline Iddare & $\mathbf{2 0 1 5}$ & $\mathbf{2 0 1 6}$ & $\mathbf{2 0 1 7}$ & $\mathbf{2 0 1 8}$ & Ortalama \\
\hline Adana & 1 & 4 & 5 & 5 & 3,75 \\
\hline Ankara & 5 & 4 & 4 & 3 & 4,00 \\
\hline Antalya & 0 & 6 & 9 & 4 & 4,75 \\
\hline Aydın & 0 & 1 & 1 & 2 & 1,00 \\
\hline Balıkesir & 0 & 2 & 3 & 3 & 2,00 \\
\hline Bursa & 6 & 11 & 9 & 2 & 7,00 \\
\hline Denizli & 0 & 3 & 2 & 6 & 2,75 \\
\hline Diyarbakır & 2 & 7 & 2 & 10 & 5,25 \\
\hline Erzurum & 9 & 1 & 1 & 5 & 4,00 \\
\hline Eskişehir & 0 & 3 & 9 & 3 & 3,75 \\
\hline Gaziantep & 1 & 3 & 2 & 3 & 2,25 \\
\hline Hatay & 1 & 2 & 11 & 4 & 4,50 \\
\hline İstanbul & 4 & 7 & 8 & 6 & 6,25 \\
\hline İzmir & 0 & 17 & 13 & 5 & 8,75 \\
\hline K.Maraş & 0 & 3 & 3 & 0 & 1,50 \\
\hline Kayseri & 0 & 5 & 6 & 6 & 4,25 \\
\hline Kocaeli & 2 & 4 & 2 & 9 & 4,25 \\
\hline Konya & 2 & 6 & 5 & 5 & 4,50 \\
\hline Malatya & 11 & 1 & 0 & 3 & 3,75 \\
\hline Manisa & 2 & 5 & 3 & $0 *$ & 2,50 \\
\hline Mardin & 1 & 3 & 2 & 1 & 1,75 \\
\hline Mersin & 0 & 11 & 6 & 3 & 5,00 \\
\hline Muğla & 0 & 18 & 3 & 3 & 6,00 \\
\hline Ordu & 6 & 2 & 3 & 2 & 3,25 \\
\hline Sakarya & 4 & 21 & 5 & 4 & 8,50 \\
\hline Samsun & 4 & 4 & 2 & 6 & 4,00 \\
\hline Şanlurfa & $0 *$ & 0 & 6 & 1 & 1,75 \\
\hline Tekirdağ & 0 & 0 & 3 & 0 & 0,75 \\
\hline Trabzon & 2 & 1 & 7 & 2 & 3,00 \\
\hline Van & 4 & 1 & 9 & 2 & 4,00 \\
\hline Toplam Bulgu & 67 & 156 & 144 & 108 & 3,95 \\
\hline Ortalama Bulgu Daylsi & $\mathbf{2 , 2 3}$ & $\mathbf{5 , 2 0}$ & $\mathbf{4 , 8 0}$ & $\mathbf{3 , 6 0}$ & $\mathbf{3 , 9 5}$ \\
\hline
\end{tabular}

Kaynak: Sayıştay Başkanlığı Kamu İdareleri Denetim Raporlarından yararlanılarak hazırlanmıștır.

*Denetim görüşünü etkilemeyen bulgular idareler özelinde düşük bir seyir göstermekte iken bazı idarelerde denetim görüşünü etkilemeyen bulguların sayısı dikkat çekecek derecede yüksek olduğu tespit edilmiştir.

Yukarıdaki tabloya göre otuz büyükşehir belediyesi özelinde Sayıștay tarafından her yıl düzenli olarak denetim yapıldığı görülmektedir. Ortalama bulgu sayısının ise 3,95 adet olduğu, kimi idarelerde bulgu sayısının zaman zaman dikkat çekecek derecede arttığı gözlemlenmektedir. Manisa ve Şanlıurfa'da Sayıştay tarafindan denetim görüşünü etkileyecek bulgu tespit edilememiş olsa da denetim görüşünü etkilemeyen çok sayıda bulguya yer verildiği görülmüştür. 2015 yılında Şanlıurfa Büyükşehir Belediyesinde 46 adet, 2018 y1lında da Manisa Büyükşehir Belediyesinde 17 adet denetim görüşünü etkilemeyen bulguya yer verildiği tespit edilmiştir.

Tablo 8: Büyükşehir Belediyelerine Bağlı İdarelerde Sayıştay Denetimi Bulgu Sayıları

\begin{tabular}{|l|c|c|c|c|c|}
\hline Idare & $\mathbf{2 0 1 5}$ & $\mathbf{2 0 1 6}$ & $\mathbf{2 0 1 7}$ & $\mathbf{2 0 1 8}$ & Ortalama \\
\hline Adana ASKI & 3 & - & 0 & - & 1,50 \\
\hline Ankara EGO & 0 & 2 & 6 & 2 & 2,50 \\
\hline
\end{tabular}




\begin{tabular}{|c|c|c|c|c|c|}
\hline ASKİ & 0 & 3 & 6 & 6 & 3,75 \\
\hline ASAT & 0 & 3 & 2 & 2 & 1,75 \\
\hline Aydın ASKİ & 0 & - & - & 4 & 2,00 \\
\hline Balıkesir BASKİ & 1 & - & $4 *$ & - & 2,50 \\
\hline Bursa BUSKİ & 2 & 7 & 5 & 4 & 4,50 \\
\hline Denizli DESKİ & 5 & - & - & 4 & 4,50 \\
\hline Diyarbakır DESKİ & 2 & - & - & - & 2,00 \\
\hline Erzurum ESKİ & 1 & - & - & - & 1,00 \\
\hline Eskişehir ESKİ & 0 & 2 & 0 & - & 0,67 \\
\hline Gaziantep GASKİ & 1 & 2 & 3 & 4 & 2,50 \\
\hline Hatay HATSU & 2 & - & 2 & - & 2,00 \\
\hline İstanbul İETT & 1 & 1 & 0 & - & 0,67 \\
\hline İstanbul İSKİ & 0 & $0 *$ & 3* & 0 & 0,75 \\
\hline İzmir İZSU & 0 & 4 & 2 & - & 2,00 \\
\hline İzmir ESHOT & 3 & - & - & - & 3,00 \\
\hline K.Maraş KASKİ & 0 & - & - & - & 0,00 \\
\hline Kayseri KASKİ & 0 & - & - & - & 0,00 \\
\hline Kocaeli İSU & 3 & 2 & 2 & - & 2,33 \\
\hline Konya KOSKİ & 0 & 3 & - & - & 1,50 \\
\hline Malatya MASKİ & 0 & - & 0 & - & 0,00 \\
\hline Manisa SUKİ & 2 & - & 3 & 0 & 1,67 \\
\hline Mardin MARSU & 0 & - & - & - & 0,00 \\
\hline Mersin MESKİ & 0 & - & 5 & - & 2,50 \\
\hline Muğla MUSKİ & 2 & - & 1 & 2 & 1,67 \\
\hline Ordu OSKİ & 1 & 1 & 0 & - & 0,67 \\
\hline Sakarya SASKI & 1 & 2 & - & - & 1,50 \\
\hline Samsun SASKİ & 3 & 1 & 3 & - & 2,33 \\
\hline Şanlıurfa ŞUSKİ & 0 & - & - & - & 0,00 \\
\hline Tekirdağ TESKİ & 2 & - & 6 & - & 4,00 \\
\hline Trabzon TISSKI & 2 & 0 & 0 & - & 0,67 \\
\hline Van VASKİ & 2 & - & 3 & - & 2,50 \\
\hline Toplam & 37 & 33 & 49 & 28 & \\
\hline Ortalama Bulgu Dayıst & 1,23 & 2,5 & 2,2 & 2,8 & 2,18 \\
\hline
\end{tabular}

Kaynak: Sayıştay Başkanlığı Kamu İdareleri Denetim Raporlarından yararlanılarak hazırlanmıştır.

*Denetim görüşünü etkilemeyen bulgular idareler özelinde düşük bir seyir göstermekte iken bazı idarelerde denetim görüşünü etkilemeyen bulguların sayısı dikkat çekecek derecede yüksek olduğu tespit edilmiştir.

Yukarıdaki tabloya göre büyükşehir belediyelerine bağlı olan idareler özelinde Sayıştay tarafından her yıl düzenli olarak denetim yapılmamış olup, 2015 yılında bütün idareler özelinde yapılan denetim, izleyen yıllarda kısmen gerçekleşmiştir. Tabloda yer alan nihai ortalamalar ise denetim yapılan idare sayısı esas alınarak hesaplanmıştır. Buna göre Sayıştay tarafından yapılan denetimler neticesinde düzenlenen raporlarda yer alan ortalama bulgu sayıs1 2,18'dir. Su ve kanalizasyon idarelerinin özel amaçlı birer hizmet kurumu olması sebebiyle bulgu sayısının büyükşsehir belediyelerinden az olması dikkat çekmektedir.

Büyükşehir belediyelerinde olduğu gibi su ve kanalizasyon idarelerinde de yapılan denetimlerde denetim görüşünü etkilemeyen bulgulara yer verilmekte olup, bazı idarelerde bu sayısının dikkat çekici olduğu görülmektedir. İSKİ'de 2016 yılında gerçekleşen denetimde, denetim görüşünü etkileyen bulgu yer almazken denetim görüşünü etkilemeyen 25 adet bulguya yer verilmiştir. 2017 y1lı denetim raporunda ise 3 bulgunun dışında 24 adet denetim görüşünü etkilemeyen bulguya da yer verildiği görülmüsştür. 2017 yılında ise Balıkesir $\mathrm{Su}$ ve Kanalizasyon İdaresi Genel Müdürlügünde 34 adet denetim görüşünü etkilemeyen bulguya yer verilmiştir.

Ancak 2016 yılında İSKİ özelinde denetim görüşünü etkilemeyen bir bulgu üzerinde bir değerlendirmeye gidilmesine gerek olduğu anlaşılmaktadır. Söz konusu denetim görüşünü etkilemeyen 3 no.lu bulgu "Kurumun Harcamalara Katılma Payı Hesaplama Yönteminin Belediye Gelirleri Kanunu'na Uygun Olmaması" şeklindedir (Sayıştay, 2017: 29). Anılan bulgunun açıklanmasında ise "su ve kanalizasyon tesisleri yapılması nedeniyle, bunlardan faydalanan gayrimenkul sahiplerinden alınan harcamalara katılma paylarının 2464 sayılı Belediye Gelirleri Kanunu'nda öngörülen şekilde hesaplanmadığı tespit edilmiştir. Kurumca yapılan gerçek giderlerin ve emlak vergisine esas değerlerin nazara alınmadığı, bunun yerine İSKİ Tarifeler Yönetmeliği ile yeni bir hesaplama yöntemi belirlenerek Kanun'a aykırı işlem tesis edildiği görülmüştür" denilmiştir. Dolayısıyla harcamalara katılma payının eksik veya fazla alınmasına mahal verecek derecedeki bu 
uygunsuzluğun mali rapor ve tabloları etkileyeceği açıktır. Aynı husus 2017 yılı denetiminde Balıkesir Su ve Kanalizasyon İdaresinde de geçerli olup denetim görüşünü etkilemeyen 31'inci bulgu "Yapımı Tamamlanan Su ve Kanalizasyon Tesislerinden Harcamalara Katılım Payı Alınmaması" olup (Sayıştay, 2018: 73), tahsil edilmesi gerekirken edilmeyen ve dolayısıyla da kamu zararı şeklinde nitelendirilebilecek bir gelir kaybının mali rapor ve tabloları etkilemediği düşünülemez. Bu sebeple denetim görüşünü etkileyen ve etkilemeyen hususların teorik anlamda ayrımı yapılmışken uygulamada bu ayrımın raporlara yeterince yansıtılmadığı da görülmüştür.

Bütün bu açıklamalar muvacehesinde; Sayıştay tarafindan yapılan yıllık denetimlerde büyükşehir belediyelerinde ortalama bulgu sayısının 3,95, bağlı idareler özelinde de ortalama bulgu sayısının 2,18 olduğu, anılan bulguların yoğunlukla muhasebe kayıtları ile mali konulardaki uygulama hataları olduğu görülmüştür. Bulgular ise idareler arasında büyük ölçüde benzeşmekle birlikte, "iç denetim faaliyetinin etkinliğii" noktasında iç denetim faaliyetinin olmadığı kimi yerlerde bu hususun bulgu konusu yapıldığ bulguya yer verilmediği görülmüştür. Dolayısıyla Sayıştay denetiminin idareler arasında yeterli eşgüdümü ve yeknesaklığı sağlayamadığı değerlendirilmiştir.

\section{BÜYÜKŞEHİR BELEDIYYLERİ İLE BAĞLI İDARELERDE İÇ DENETIMİN ETKİNLİĞi̇: MERSIN ÖRNEĞİ}

Sayıştay Başkanlığı tarafindan yapılan denetimlerde denetim raporu sayısından ziyade bulgu sayısı üzerinden bir değerlendirmeye gidilmesi gerekirken, iç denetim faaliyetinde öncelikle rapor sayıları üzerinden bir mukayeseye gidilmesi gerekmiştir. Ancak söz konusu raporların mahiyeti, başka bir deyişle içerdiği bulgu sayısı da önem arz etmektedir. Bu çerçevede büyükşehir belediyeleri ve bağlı idareler kapsamında tek bir kentte gerçekleştirilen iç denetim faaliyetinin ele alınması gerekmiş, denetim raporları itibariyle iç denetim sürecinin aktif bir şekilde işlediği değerlendirilen Mersin Büyükşehir Belediyesi ile Mersin Su ve Kanalizasyon İdaresi Genel Müdürlüğünün iç denetim faaliyetleri kapsamında iç denetim raporlarında yer alan bulgu adetlerinin değerlendirilmesi amaçlanmıştır.

Tablo 9: Büyükşehir Belediyelerine Bağlı İdarelerde İç Denetim Faaliyetinin Etkinliği

\begin{tabular}{|c|c|c|c|c|c|c|c|}
\hline \multirow{2}{*}{ İdare Adı } & \multicolumn{4}{|c|}{$\begin{array}{l}\text { 2015-2018 Toplam Rapor } \\
\text { Sayıs }\end{array}$} & \multirow{2}{*}{$\begin{array}{l}\text { İç } \\
\text { Denetçi } \\
\text { Sayısı }\end{array}$} & \multirow{2}{*}{$\begin{array}{l}\text { Yllık Ortalama İç } \\
\text { Denetçi Başına Düşen } \\
\text { Rapor Sayısı (Yıllık } \\
\text { Ortalama/ Denetçi) }\end{array}$} & \multirow{2}{*}{$\begin{array}{lc}\text { İç Denetçi Başına } \\
\text { Düssen Rapor } \\
\text { Sayısı (Toplam } \\
\text { Rapor/ Denetçi) }\end{array}$} \\
\hline & Dn. & Da. & İnc. & Toplam & & & \\
\hline $\begin{array}{l}\text { Mersin } \quad \text { Su ve } \\
\text { Kanalizasyon İdaresi } \\
\text { Genel Müdürlüğü }\end{array}$ & 10 & 8 & 21 & 39 & 1 & 9,75 & 39,00 \\
\hline $\begin{array}{l}\text { Mersin Büyükşehir } \\
\text { Belediyesi }\end{array}$ & 46 & 39 & 2 & 87 & 7 & 3,10 & 12,42 \\
\hline
\end{tabular}

Yukarıda yer alan tablo daha önce büyükşehir belediyeleri ile bağl1 idareler özelinde hazırlanan tablolardan edinilmiş olup, Mersin kenti kapsamında diğer büyükşehir belediyelerine nazaran iç denetim faaliyetinin daha etkin yürütüldüğü gözlemlenmiştir. Yukarıda da değinildiği üzere söz konusu denetimler özelinde bulgu sayılarının önem taşıması nedeniyle bahsi geçen idareler ile iletişime geçilerek iç denetim faaliyeti kapsamındaki toplam rapor sayıları, raporların ilgili olduğu birimler ile toplam bulgu sayıları edinilmiştir. Aşağıda yer alan tablolarda verilen bulgu sayıları sadece denetim raporları özelinde tespit edilen bulguları içermekte olup, inceleme ve danışmanlık raporlarında belirli bir konu veya sürecin iç denetim faaliyeti kapsamına alınması nedeniyle bu konular bulgu sayısına dâhil edilmemiştir.

Tablo 10: Mersin Büyükşehir Belediyesinde İç Denetim Faaliyetinin Etkinliği

\begin{tabular}{|c|c|c|c|}
\hline $\begin{array}{l}\text { Mersin Büyükşehir } \\
\text { Belediyesi }\end{array}$ & $\begin{array}{l}\text { Denetim-Danışmanlık ve } \\
\text { Inceleme Rapor sayısı }\end{array}$ & $\begin{array}{l}\text { Raporların ilgili olduğu } \\
\text { birim sayısı }\end{array}$ & Toplam Bulgu sayısı \\
\hline 2015 & 12 & 11 & 141 \\
\hline 2016 & 11 & 8 & 80 \\
\hline 2017 & 19 & 13 & 99 \\
\hline 2018 & 45 & 37 & 6 \\
\hline 2019 & 2 & 2 & 102,6 \\
\hline Ortalama & 17,8 & 14,2 & 107 \\
\hline
\end{tabular}

Kaynak: İlgili idare ile yapılan görüşme ve yazılı başvuru neticesinde edinilen bilgilerden hareketle derlenmiştir. 
Yukarıdaki tabloya göre Mersin Büyükşehir Belediyesi özelinde yıllık ortalama rapor sayısının 17,8 olduğu, söz konusu raporların ise idare genelinde farklı hizmet türlerinde faaliyet gösteren birçok birimi ilgilendirdiği, anılan yıllar arasında tespit edilen ortalama bulgu sayısının ise 102,6 olduğu, bu çerçevede İDKK tarafından yedi adet iç denetçi kadrosunun ihdas edildiği ve bu kadroların tamamının dolu olduğu, buna istinaden de etkin bir iç denetim faaliyetinin yürütüldüğü, 2015-2018 yılları arasında iç denetçi başına 3,10 rapor, 2015-2019 döneminde de 2,54 adet rapor düştüğ̈̈ görülmüştür. Genel yönetim kapsamındaki idarelerde mezkûr ortalamanın 1,73 olduğu, büyükşehir belediyelerinde 2,46, bağl1 idarelerde de 2,67 olan ortalama rapor sayısı dikkate alındığında Mersin Büyükşehir Belediyesinde iç denetim faaliyetinin etkin bir şekilde ifa edildiği anlaşılmaktadır. Diğer taraftan ortalama yıllık bulgu sayısının yaklaşık 102,6 adet olduğu dikkate alınırsa aynı idare özelinde Sayıştay tarafından da ortalama 5 bulgunun tespit edildiği görülmektedir. Bu verilerden hareketle iç denetim faaliyetinin söz konusu idarede diğer denetimlere göre etkin bir şekilde yürütüldüğü anlaşılmaktadır.

Diğer taraftan iç denetim birimlerinde en az üç iç denetçi olması halinde İç Denetim Birimi Başkanlıkları teşekkül ettirilmekte, buna bağlı olarak da bir başkan görevlendirilmektedir. İç-Den adlı bir yazılım marifetiyle yürütülen denetimlerde ise denetimin nihayete erebilmesi için iç denetçi ve denetim gözetim sorumlusu görevlendirilmekte, iç denetçinin denetim faaliyeti denetim gözetim sorumlusunca izlenmekte, akabinde de iç denetim birimi başkanının onayıyla denetim raporu üst yöneticiye gönderilmektedir. $\mathrm{Bu}$ çerçevede her bir denetim faaliyeti için denetim gözetim sorumlusu da görevlendirilmekte olup, başkan dışındaki altı iç denetçinin üç adedinin aktif denetim yaparken diğerlerinin denetim gözetim sorumlusu olması nedeniyle ortalama rapor sayısının düşük bir seviyede gerçekleştiği, ancak buna rağmen özellikle bulgu sayısı da nazara alındığında iç denetim faaliyetinin genel ortalamanın üzerinde olduğu değerlendirilmektedir.

Aşağıda ise yine bu idareye bağlı olmakla birlikte ayrı bir bütçesi ve tüzel kişiliği olan Mersin Su ve Kanalizasyon İdaresi Genel Müdürlüğünün iç denetim faaliyetine dair verilere yer verilmiştir.

Tablo 11: Mersin Su ve Kanalizasyon İdaresi Genel Müdürlüğü İç Denetim Faaliyetinin Etkinliği

\begin{tabular}{|c|c|c|c|}
\hline $\begin{array}{l}\text { Mersin Su } \quad \text { ve } \\
\text { Kanalizasyon } \\
\text { İdaresi } \\
\begin{array}{l}\text { Müdürlüğüu } \\
\text { Genel }\end{array} \\
\end{array}$ & $\begin{array}{l}\text { Denetim-Danışmanlık } \\
\text { İnceleme Rapor sayısı }\end{array}$ & $\begin{array}{l}\text { Raporların ilgili olduğu } \\
\text { birim sayısı }\end{array}$ & Toplam Bulgu sayısı \\
\hline 2015 & 17 & 16 & 54 \\
\hline 2016 & 16 & 8 & 63 \\
\hline 2017 & 3 & 14 & 19 \\
\hline 2018 & 3 & 4 & 7 \\
\hline 2019 & 3 & 4 & 13 \\
\hline Ortalama & 8,4 & 9,2 & 31,2 \\
\hline
\end{tabular}

Kaynak: İlgili idare ile yapılan görüşme ve yazılı başvuru neticesinde edinilen bilgilerden hareketle derlenmiştir.

Yukarıdaki tabloya göre MESKİ Genel Müdürlüğü özelinde yıllık ortalama rapor sayısının 8,2 olduğu, söz konusu raporların ise idare genelinde birçok birimi ilgilendirdiği, anılan yıllar arasında tespit edilen ortalama bulgu sayısının ise 31,2 olduğu, bu çerçevede İDKK tarafından üç adet iç denetçi kadrosunun ihdas edildiği mezkûr idare özelinde tek iç denetçi ile etkin bir iç denetim faaliyetinin yürütüldüğü, 2015-2018 yılları arasında iç denetçi başına 9,75 rapor, 2015-2019 döneminde de 8,4 adet rapor düştüğü görülmüştür. Genel yönetim kapsamındaki idarelerde mezkûr ortalama 1,73, büyükşsehir belediyelerinde 2,46 , bağlı idarelerde de 2,67 olan ortalama rapor sayısı dikkate alındığında söz konusu idarede iç denetim faaliyetinin etkin bir şekilde ifa edildiği anlaşılmakla birlikte ortalama yıllık bulgu sayısının da yaklaşık 31 adet olduğu, aynı idare özelinde Sayıştay tarafindan da ortalama 2,5 bulgunun tespit edildiği görülmektedir. Bu verilerden hareketle iç denetim faaliyetinin oldukça ayrıntılı bir denetim faaliyeti olduğu anlaşılmaktadır.

\section{SONUÇ}

Nüfusun önemli bir kısmının yaşadığı büyükşehir belediyelerinde, giderek farklılaşan ve teknolojik gelişmelerle beraber sunum süreçleri değişen mahalli müşterek hizmetler önemli ölçüde büyükşsehir belediyeleri ile bağlı idareleri tarafından sunulmaktadır. Özellikle kamu yönetimi paradigmalarındaki değişikliklerle beraber bu hizmetlerin sunumunda vatandaş memnuniyetinin esas belirleyici haline geldiği görülmektedir. Buna bağlı olarak da mahalli müşterek hizmetlerin belirlenen usul ve esaslara göre sunulmas1 gerekmiştir. Bu çerçevede anılan hizmetlerin yönetilmesinde denetimin önemi de kayda değer derecede artmıştır. Yine bu değişimle beraber geleneksel teftiş yöntemi iç denetime verilmiştir. Türkiye'de de 5018 
sayılı Kamu Mali Yönetimi ve Kontrol Kanunu ile iç denetim faaliyeti uygulama alanı bulmuş, buna istinaden de genel yönetim kapsamındaki idarelere iç denetçi kadroları ihdas edilmiştir.

Büyükşsehir belediyeleri ile bağlı idarelerinde gerçekleştirilen iç denetim faaliyetinin etkinliğini değerlendirmek maksadıyla İDKK raporları ile Sayıştay Denetimi bulgularının veri olarak kullanılması gerektiği kanaatine varılmış, söz konusu idarelerde gerçekleştiren iç denetim faaliyeti genel yönetim kapsamındaki idarelerdeki iç denetim faaliyeti verileri ile Sayıştay denetimi bulguları ile mukayese edilmesi gerekmiştir

Türkiye'de genel olarak iç denetim faaliyetinin beklenilen düzeye ulaşmadığı, yine ihdas edilen iç denetçi kadrolarının önemli bir kısmına atama yapılmadığı tespit edilmiştir. Başka bir deyişle ihdas edilen iç denetçi kadrolarının \%58'inin hala boş olduğu ve bu kadrolara atama yapılmadığı gibi genel yönetim kapsamında olup iç denetçi atamayan 123 adet idarenin de bulunduğu anlaşılmıştır. Dolayısıyla iç denetimin etkinliğinin yeterli düzeye ulaşmadığı görülmektedir.

Türkiye genelinde iç denetim faaliyetinin sürdürüldüğü 253 idarede 2015-2018 yılları arasında 6.021 adet rapor tanzim edildiği, iç denetçi başına düşen rapor adetinin de 1,73 olduğu, büyükşehir belediyelerinde ise 15 adet idarede iç denetim faaliyetinin sürdürüldüğü, bu idarelerde de iç denetçi başına düşen ortalama rapor sayısının 2,46 olduğu, bağl idarelerde de bu sayısının 2,67 olduğu tespit edilmiştir.

Sayıştay Başkanlığınca yürütülen denetimlerde ise büyükşehir belediyelerinde ortalama bulgu adetinin 3,95 olduğu, bağlı idarelerde ise bulgu ortalamasının 2,18 olduğu tespit edilmiştir. İç denetim faaliyetinin etkinliğinin anlaşılması için büyükşehir belediyeleri ve bağlı idareler özelinde yıllık ortalama rapor sayısı dikkat çeken Mersin ili inceleme kapsamına alınmıştır. 2015-2018 yılları arasında Mersin Büyükşehir Belediyesinde iç denetçi başına ortalama rapor sayısı 3,1 iken Mersin Su ve Kanalizasyon İdaresinde ise bu sayının 9,75 adet olduğu tespit edilmiştir. Anılan raporların içerisinde ise denetim raporları esas alındığında ise Mersin Büyükşehir Belediyesinde 2015-2019 yılları arasında yıllık ortalama bulgu sayısının 102 adet olduğu, MESKİ Genel Müdürlüğünde de ortalama bulgu sayısının 31 adet olduğu, Sayıştay denetimleri neticesinde de Mersin Büyükşehir Belediyesinde ortalama bulgu sayısı 5 adet iken MESKİ Genel Müdürlüğünde bu sayının 2,5 olduğu tespit edilmiştir. Bulguların mahiyeti incelendiğinde ise iç denetim bulgularının oldukça mikro ölçekte ayrıntılı uygunsuzlukları içerdiği görülürken, Sayıştay bulgularının ise makro düzeyde ve sınırlı sayıda oldukları görülmüştür. Bu nedenle iç denetimin dış denetime nazaran daha etkili ve iyileştirmeye açık noktalara işaret ettiği, bu hususları sürekli izleme faaliyeti ile takip ederek sürekli bir iyileştirme sürecini sağladığı anlaşılmıştır. Sayıştay denetiminin ise yıllık yapılması ve belirli konularda yoğunlaşması sebebiyle daha makro düzeyde bir denetim sürecine tekabül ettiği değerlendirilmektedir.

Öte yandan iç denetim faaliyetinin üst yöneticinin iç denetime olan bakış açısına göre işlerlik kazanabildiği, bazı idarelerde iç denetçinin yetkinliklerine göre denetim veya danışmanlık faaliyetlerinin sayılarının arttığı, bazı idarelerde de raporların konularının bazı uzmanlık alanlarında ve birimler özelinde yoğunlaştığı görülmektedir. Bu sebeple iç denetçi kadrolarına yapılan atamalar tamamlansa dahi üst yönetiminin iç denetimden beklentileri ölçüsünde iç denetim faaliyetinin işlerlik kazanabileceği açıktır. Bu nedenle yönetim erkleri ile iç denetçilerin risklerin belirlenmesi ve bulguların gereğinin yerine getirilmesi noktasında etkin bir iş birliği tesis etmesi gerekmektedir.

Diğer taraftan bir idarede iç denetim biriminin teşekkül ettirilmemesi ve iç denetçi kadrolarına atama yapılmayarak iç denetim faaliyetinin işler hale getirilmemesi durumunun kimi büyükşehir ve bağlı idarelerinde Sayıştay tarafından bulgu haline getirilmesine rağmen yine aynı denetim erki tarafından bu durumun diğer idareler özelinde bulgu haline getirilmediği örneklere de rastlanılmıştır. Söz konusu durum Sayıştay denetiminde eşgüdüm ve yeknesaklığın tam olarak sağlanamadığını da ortaya koymaktadır. Bu sebeple Sayıştay tarafından iç denetimin etkinliğinin sürekli olarak değerlendirilmesi gerekirken İDKK tarafından iç denetim faaliyetinin genel yönetim kapsamındaki idareler kapsamında daha etkin hale getirilmesi için iç denetçi kadrolarının doldurulması noktasında idareleri teşvik edici aksiyonlar alması gerekmektedir.

Hâlihazırda iç denetim faaliyetinin yeterince etkin olması için gerekli olan koşulların mevcut bulunduğu, büyükşehir belediyeleri ve bağlı idareler açısından Mersin örneği de dikkate alındığında iç denetimin yerel hizmetlerin ifasında iyileştirici bir aksiyon üstlendiği, bu sebeple iç denetimin etkinliğinin tesis edilebilmesi için iç denetçinin yetkinliklerinin yanı sıra üst yöneticinin bu denetime bakışı ve istemlerinin de önem taşıdığ 1 , netice olarak Saysştay denetimine nazaran daha etkin olduğu değerlendirilen iç denetim faaliyetinin genel yönetim kapsamındaki idareler özelinde daha işler hale getirilerek yıllık ortalama rapor sayısının artırılması ve risk esaslı denetimin yaygınlaştırılması için IDKK tarafında gerekli önlemlerin alınması gerektiği değerlendirilmektedir. 


\section{KAYNAKÇA}

24/12/2003 tarih ve 25326 sayılı Resmî Gazetede yayımlanan 5018 sayılı Kamu Mali Yönetimi ve Kontrol Kanunu 12/7/2006 tarih ve 26226 sayılı Resmî Gazetede yayımlanan İç Denetçilerin Çalışma Usul ve Esasları Hakkında Yönetmelik

19/12/2010 tarih ve 27790 sayılı Resmî Gazetede yayımlanan 6085 sayılı Sayıştay Kanunu

Balıkesir Su ve Kanalizasyon İdaresi Genel Müdürlüğü 2017 yılı Sayıştay Denetim Raporu (2018), Sayıştay Başkanlığı, erișim tarihi 14.09.2020, https://www.sayistay.gov.tr/tr/Upload/62643830/files/raporlar/kid/2017/Belediyeler/BALIKES\%C4\%B0R\%20B ASK\%C4\%B0.pdf

Erzurum Su ve Kanalizasyon İdaresi Genel Müdürlüğü 2015 yılı Sayıştay Denetim Raporu (2016), erişim tarihi 18.09.2020,

https://sayistay.gov.tr/tr/Upload/62643830/files/raporlar/kid/2015/Belediyeler/ERZURUM\%20B\%C3\%9CY\%C 3\%9CK\%C5\%9EEH\%C4\%B0R\%20BELED\%C4\%B0YES\%C4\%B0\%20SU\%20VE\%20KANAL\%C4\%B0ZA SYON\%20\%C4\%B0DARES\%C4\%B0\%20GENEL\%20M\%C3\%9CD\%C3\%9CR\%C3\%9CL\%C3\%9C\%C4\%9 E\%C3\%9C.pdf

Hatay Büyükşehir Belediyesi 2015 yılı Sayıştay Denetim Raporu (2016), Sayıştay Başkanlığı, erişim tarihi 17.09.2020, https://www.sayistay.gov.tr/tr/Upload/62643830/files/raporlar/kid/2015/Belediyeler/HATAY\%20B\%C3\%9CY $\%$ C3\% 9CK\% $\% \% 9 E E H \% C 4 \% B 0 R \% 20 B E L E D \% C 4 \% B 0 Y E S \% C 4 \% B 0 . p d f$

Hazine ve Maliye Bakanlığının (İç Denetim Birimi başkanlığı), İç Denetim Nedir?, erişim tarihi 17.10.2020, https://ms.hmb.gov.tr/uploads/2018/11/10.-\%C4\%B0\%C3\%A7-Denetim-Nedir.pdf

IIA (2020) The Institute of Internal Auditors, erişim tarihi 17.10.2020, https://na.theiia.org/Pages/IIAHome.aspx

İDKK (2013), İç Denetim Rehberi, erişim tarihi 19/09/2020, https://ms.hmb.gov.tr/uploads/2019/09/K\%C4\%B0DR_v1.0.pdf

İDKK (2018), 2018 Yılı Güncel Dolu Boş İç Denetçi Kadroları, erişim tarihi 19/09/2020, https://ms.hmb.gov.tr/uploads/2019/09/Dolu-BosKadroSayisi.pdf

İDKK (2020a), 2015-2018 Yılları Kamu İç Denetim Faaliyet Raporu, erişim tarihi 20/09/2020, https://www.hmb.gov.tr/idkk-faaliyet-raporlari

İDKK (2020b), 2018 Yılı Kamu İç Denetim Faaliyet Raporu, erişim tarihi 19/09/2020, https://ms.hmb.gov.tr/uploads/2020/05/2018KamuIcDenetimGenelRaporu.pdf

İDKK (2020c), 2020 Y1lı Güncel Dolu Boş İ̧ Denetçi Kadroları, erişim tarihi 19/09/2020, https://www.hmb.gov.tr/kamuidareleri-ic-denetci-kadrolari

İDKK (2020d), "İç Denetçi Sayıları" konulu 02/10/2020 tarih ve 549005 sayılı yazı.

İstanbul Su ve Kanalizasyon İdaresi Genel Müdürlüğü 2016 yılı Sayıştay Denetim Raporu (2017), Sayıştay Başkanlığı, erişim tarihi

14.09.2020, https://www.sayistay.gov.tr/tr/Upload/62643830/files/raporlar/kid/2016/Belediyeler/\%C4\%B0STANBUL\%20S U\%20VE\%20KANAL \%C4\%B0ZASYON\%20\%C4\%B0DARES\%C4\%B0\%20GENEL\%20M\%C3\%9CD\%C3 $\% 9 \mathrm{CRL} \% \mathrm{C} 3 \% 9 \mathrm{C} \% \mathrm{C} 4 \% 9 \mathrm{E} \% \mathrm{C} 3 \% 9 \mathrm{C} \% 20 \% \mathrm{C} 4 \% \mathrm{~B} 0 \mathrm{SK} \% \mathrm{C} 4 \% \mathrm{~B} 0 . \mathrm{pdf}$

İSMMMO(İstanbul Serbest Muhasebeci Mali Müşavirler Odası), İç Denetime Genel Bir Bakış, erişim tarihi 4.11.2020, http://archive.ismmmo.org.tr/docs/YAYINLAR/kitaplar/ic_denetim_2015.pdf

Kayseri Büyükşehir Belediyesi 2015 yılı Sayıştay Denetim Raporu (2016), Sayıştay Başkanlığı, erişim tarihi 17.09.2020, https://www.sayistay.gov.tr/tr/Upload/62643830/files/raporlar/kid/2015/Belediyeler/KAYSER\%C4\%B0\%20B\% C3\%9CY\%C3\%9CK\%C5\%9EEH\%C4\%B0R\%20BELED\%C4\%B0YES\%C4\%B0.pdf

Mersin Büyükşehir Belediyesi (2020), "Denetime İlişkin Bilgi” konulu 24/09/2020 tarih ve 121510 sayılı yazı.

Mersin Su ve Kanalizasyon İdaresi Genel Müdürlüğü (2020), "İstatistiki Bilgi” konulu 24/09/2020 tarih ve 15894 say1lı yazi.

Sayıştay Başkanlığı (2016), Belediyeler-Bağlı İdareler 2015 Denetim Raporları, erişim tarihi 17.09.2020, https://sayistay.gov.tr/tr/?p=2\&ContentID=1899

Sayıştay Başkanlığı (2017), Belediyeler-Bağlı İdareler 2016 Denetim Raporları, erişim tarihi 17.09.2020, https://sayistay.gov.tr/tr/?p=2\&ContentID $=12124$

Sayıştay Başkanlığı (2018), Belediyeler-Bağlı İdareler 2017 Denetim Raporları, erişim tarihi 17.09.2020, https://sayistay.gov.tr/tr/?p=2\&ContentID $=12364$

Sayıştay Başkanlığı (2019), Belediyeler-Bağlı İdareler 2018 Denetim Raporları, erişim tarihi 17.09.2020, https://sayistay.gov.tr/tr/?p=2\&ContentID $=12705$

Şanlıurfa Büyükşsehir Belediyesi 2015 yılı Sayıştay Denetim Raporu (2016), Sayıştay Başkanlığı, erişim tarihi 17.09.2020,

https://www.sayistay.gov.tr/tr/Upload/62643830/files/raporlar/kid/2015/Belediyeler/\%C5\%9EANLIURFA\%20B \% C3\%9CY\%C3\%9CK\%C5\%9EEH\%C4\%B0R\%20BELED\%C4\%B0YES\%C4\%B0.pdf

The Chartered Institute of Internal Auditors, 2020, erişim tarihi 17.10.2020 https://www.iia.org.uk/about-us/what-isinternal-audit/

Uyar, Süleyman, (2009) İç Kontrol ve İç Denetim: 5018 Sayılı Kanun Açısından Değerlendirilmesi, Gazi Kitabevi, Ankara. 
Uzun, Ali Kamil, (2020) “İç Denetim Nedir?”, erişim tarihi 17.10.2020, http://www.denetimnet.net/UserFiles/Documents/Makaleler/\%C4\%B0\%C3\%A7\%20Denetim/\%C4\%B0\%C3\% A7\%20Denetim\%20Nedir-Makale.pdf 